Volume 2 Issue 2 (2018) Pages $211-218$

Jurnal Obsesi : Jurnal Pendidikan Anak Usia Dini

DOI: $10.31004 /$ obsesi.v2i2.87

\title{
Utilization of Video Blogs (Vlogs) in Character Learning in Early Childhood
}

\author{
Yenni Fitria $^{1 凶}$ dan Juwita $^{2}$ \\ Dosen FKIP Universitas Dehasen Bengkulu
}

\begin{abstract}
Abstrak
Penanganan serius perlu dilakukan untuk mengatasi krisis moral yang terjadi di Indonesia. Salah satu cara yang diusung oleh pemerintah yaitu dengan memperbaiki sikap dan tingkah laku para pelajar melalui pendidikan karakter. Pendidikan karakter dilakukan disetiap jenjang pendidikan secara terintegrasi pada mata pelajaran. Guru memilih Video Blog (Vlog) sebagai media pembelajaran karakter karena kegemaran anak pada kegiatan menonton. Oleh karena itu, penelitian ini bertujuan untuk mengetahui pemanfaatan vidoe blog(Vlog) dalam pembelajaran karakter pada anak usia dini. Metode yang digunakan adalah deskriptif kualitiatif. Dari hasil penelitian, diketahui guru PAUD Multitalent Dehasen Bengkulu, memanfaatkan vidoe blog untuk pembelajaran karakter. Guru memanfaatkan video blog untuk memperlihatkan dan menerapkan bentuk nilai-nilai karakter yang harus dimiliki oleh anak usia dini pada aktivitas keseharian mereka di sekolah. Tiga elemen penting yang dimanfaatkan guru dalam vlog tersebut adalah (1) Media berupa Video blog, (2) Kebahasaan, dan (3) Materi/isi. Dari ketiga elemen tersebut, guru memanfaatkannya untuk mempermudah dan membantu dalam pembelajaran karakter.
\end{abstract}

Kata Kunci: vlog, pembelajaran karakter,anak usia dini

\begin{abstract}
Moral crisis that occurred in Indonesia need to be handling seriously. One way that is carried out by the government is by fix student's attitudes and behavior through character education. Character education is integrated to each subject in every level. The teacher chooses a Video Blog (Vlog) as a character learning media because of the children's passion for watching activities. Therefore, this research aims to determine video blog usage (Vlog) for character learning in early childhood. The method used is descriptive quality. From the results of the reseach, it was known that the Multitalent PAUD Dehasen Bengkulu teacher took advantage of the video blog for character learning. The teacher uses the video blog to show and apply the form of character values that early childhood must have in their daily activities at school. There are three important elements used by the teacher in the vlog are (1) Media in the form of video blogs, (2) Language, and (3) Content / content. Of the three elements, the teacher uses it to facilitate and assist in character learning.
\end{abstract}

Keywords: vlog, character learning, early childhood

@ Jurnal Obsesi Prodi PG-PAUD FIP UPTT 2018

$\triangle$ Corresponding author :

Address : Bengkulu, Indonesia

Email : yennifitria@unived.ac.id

ISSN 2356-1327 (Media Cetak)

ISSN 2549-8959 (Media Online) 


\section{PENDAHULUAN}

Perilaku-perilaku menyimpang yang terjadi di masyarakat, merupakan pukulan berat bagi perkembangan mental generasi penerus bangsa. Berbagai kasus moral yang terjadi di Indonesia menjadikan negeri ini mengalami krisis moral. Terlebih jika pelakunya adalah anak-anak usia sekolah atau berstatus sebagai pelajar. Tontonan-tontonan yang tidak layak merupakan salah satu pemicu terjadinya perbuatan tidak terpuji tersebut. Apalagi jika orang tua lengah dalam mengawasi tontonan anak-anak. Untuk menjaga agar anak-anak bangsa tidak terkontaminasi, diperlukan usaha menangkal melalui pendidikan. Pendidikan yang sedang digalakkan saat ini adalah pendidikan karakter. Pendidikan karakter merupakan upaya membantu perkembangan jiwa anak-anak baik lahir maupun batin dari sifat kodrati menuju ke arah peradaban manusiawi yang lebih baik (Mulyasa, 2011). Tidak heran jika nilai-nilai karakter yang harus dimiliki oleh peserta didik ditanamkan sejak dini. Mulai dari tingkatan paling rendah yaitu pendidikan anak usia dini hingga perguruan tinggi.

Menurut Undang-Undang Sisdiknas tahun 2003, anak usia dini adalah anak yang berusia sejak lahir sampai enam tahun (Mulyani, 2016). Berbeda batasan umur yang diungkapkan oleh The National Asoociation for Education for Young Children (NAECY), rentang usia dini (early childerhood) yaitu sejak lahir hingga usia delapan tahu. (Mulyani, 2016) Dengan begitu, semakin rendah tingkat pendidikan, maka akan semakin berat tugas guru dalam menanamkan nilai-nilai karakter. Terlebih lagi, pembelajaran pada anak usia dini memiliki prinsip-prinsip yang berbeda dari jenjang usia lainnya.

Pembelajaran karakter pada anak usia dini dilakukan dengan melibatkan secara langsung pada aktivitas yang menyenangkan. Pendidikan karakter bukanlah pembelajaran yang hanya berdasarkan teori saja, terlebih ini akan diterapkan oleh anak usia dini. Namun, pembelajaran karakter haruslah direncanakan agar peserta didik lebih mengenal, peduli dan menginternalisasi nilai-nilai karakter (Hudiyono, 2012)

Anak-anak menghabiskan sebagian waktu mereka untuk belajar di sekolah. Sehingga menjadi tanggung jawab guru untuk dapat memberikan pengalamanpengalaman kepada anak didik dalam menanamkan karakter-karakter yang baik di sekolah. Oleh karena itu, Guru berperan sangat penting dalam menyukseskan pembelajaran karakter di sekolah. Tugas guru menjadi lebih berat karena penanaman karakter ini bukan hanya sebatas teori, namun harus benar-benar berkesan dan tertanam dalam diri peserta didik terlebih bagi anak usia dini. Pembelajaran karakter dimulai dari usia dini sehingga dapat membentuk perilaku berkarakter yang baik dalam kehidupan sehari-hari.

Guru dapat menggunakan media pembelajaran untuk menanamkan nilainilai karakter sehingga kreativitas guru sangat dibutuhkan agar pembelajaran karakter bisa diterima dengan baik oleh siswa. Untuk itu seorang guru harus mampu memilih dan menggunakan media yang menarik serta dapat membantu anak didik merasakan pengalaman langsung tanpa harus ke lokasi. Guru dapat membawa peristiwa-peristiwa mengandung nilai-nilai karakter yang baik ke dalam kelas melaluiu media. Media yang digunakan adalah media kekinian yang sudah cukup dikenal yaitu penggunaan media video blog.

Video blog atau vlog adalah video yang dimuat di dalam blog untuk mempercantik tampilan weblog yang menampilkan ide-ide atau pemikiran (Komputer, 2008). Vlog menyajikan isi berupa multimedia yang meliputi gambar bergerak, kumpulan teks dan audio yang dibuat oleh conten creator atau yang lebih dikenal dengan vlogger. Vlogger adalah orang yang membuat video blog tanpa terlalu memperhatikan tujuan menghasilkan uang termasuk tanpa harus tergabung dengan media partner lainnya (Kamaru, 2018). Pembuatan vlog biasanya untuk dokumentasi pribadi yang dbagikan 
secara daring di media sosial atau internet dengan menggunakan gawai.

Pengemasan media yang menarik dan tepat sasaran menjadi penentu keberhasilan dalam usaha menanamkan nilai-nilai karakter pada anak usia dini. Media pembelajaran merupakan perantara dalam menyampaikan pesan pendidikan (Sanjaya, 2006:163) yang bertujuan untuk mendekatkan anak pada kondisi yang sebenarnya Nilai-nilai karakter yang harus ditanamkan kepada anak usia dini, terdapat di setiap aktivitas yang mereka lakukan. Oleh karena itu, penelitian ini dirasa sangat penting untuk dilakukan agar memberikan kemudahan bagi guru dalam menanamkan nilai-nilai karakter pada anak usia dini dengan memanfaatkan video blog sebagai media pembelajaran karakter. Pembelajaran karakter dilakukan secara terencana dan terus menerus. Agar pembelajaran tersebut berhasil, maka menggunakan contoh yang tidak jauh dari dari siswa atau bisa langsung dilihat Hal ini diSebabkan karena pendidikan karakter pada dasarnya adalah usaha sadar untuk memberdayakan dan mengembangkan seluruh potensi peserta didik untuk membentuk karakter baik (good character) (Suyra, 2017)

Oleh karena itu, penelitian ini akan melihat cara guru memanfaatkan video blog untuk pembelajaran karakter pada anak usia dini. Sehingga akan terlihat sejauh mana vlog yang dimanfaatkan guru untuk pembelajaran dapat membantu guru menanamkan nilai-nilai karakter pada anak usia dini.

Selanjutnya guru diharapkan akan lebih produktif menghasilkan video blog pembelajaran yang menarik, menyenangkan dan dipahami penonton terutama anak usia dini.

Selain itu, guru dapat menemukan metode dan media pembelajaran karakter pada anak usia dini. Bukan itu saja, media dan metode yang dibuat oleh guru dengan mudah dapat digunakan oleh guru lain.

Jika selama ini guru menggunakan vlog untuk pembelajaran hanya untuk di sekolahnya, ke depannya guru lain juga dapat menggunakan media dan metode yang sama dalam pembelajaran karakter.

Dengan begitu akan ada perbandingan cara dan hasil yang didapatkan dalam pemanfaatan vlog dalam pembelajaran karakter. Kalau ini dapat dilakukan maka dapat diteliti mengenai keefektifan media dan metode dalam pembelajaran karakter pada anak usia dini.

\section{METODE PENELITIAN}

Metode yang digunakan dalam penelitian ini adalah deskriptif kualitatif yang dilakukan di Paud Multitalent Dehasen Bengkulu dengan guru sebagai subjek penelitian pada tahun ajaran 2017/2018 dengan teknik analisis data sebagai berikut:

1. Pengumpulan Data. Observasi secara intensif menggunakan instrumen lembar observasi dilakukan untuk mengumpulkan data dengan menggunakan catatan pengamatan bagi guru dan sisw.

2. Reduksi Data. Klasifikasi dan kategori data penelitian berdasarkan pemanfaatan video blog dalam pembelajaran karakter pada anak usia dini.

3. Penyajian Data.Membuat analisis data dari hasil reduksi data.

4. Simpulan. Setelah melakukan analisis data, akan dirumuskan kesimpulan dari langkah-langjah yang telah dilakuakan.

5. Verifikasi. Simpulan yang sudah dibuat diverifikasi agar dapat menggambarkan keselurhan penelitian

\section{HASIL DAN PEMBAHASAN}

Setiap tindakan yang dilakukan memiliki karakter yang harus diterapkan mulai dari diri anak secara individu. Lembaga PAUD sebagai lembaga sekolah formal yang membantu menerapkan pendidikan berkarakter pada anak-anak usia dini (Prasanti \& Fitriani, 2018)

Guru memanfaatkan tiga komponen dari vlog, yaitu:

\section{Komponen Media}

Peristiwa dalam kehidupan sehari-hari yang akan dijadikan contoh bisa dihadirkan dihadapan anak di dalam kelas dengan 
menggunakan media pembelajaran. Media pembelajaran merupakan perantara dalam menyampaikan pesan pendidikan (Sanjaya, 2006) yang bertujuan untuk mendekatkan anak pada kondisi yang sebenarnya.

Guru memanfaatkan media yang dibuat menarik dengan kualitas yang sudah divalidasi oleh ahli Media. Kualitas gambar yang bagus, dengan durasi yang tidak terlalu lama guru berhasil menarik perhatian siswa untuk dapat memberikan pembelajaran karakter. Bentuk-bentuk penerapan nilai-nilai karakter bisa langsung dilihat oleh siswa. Tema dan kesesuaian dengan pembelajaran sudah disesuaikan.

2. Komponen Bahasa.

Guru juga memanfaatkan bahasa yang digunakan dalam vlog ini untuk memberikan kemudahan siswa memahami apa yang diharapkan oleh guru. Dengan bahasa yang sederhana dan mudah dipahami, anak usia dini lebih fokus menyaksikan vlog tersebut. Kebahasaan dalam video ini juga telah melewati proses validasi dari validator bahasa. Bahasa yang digunakan memang disesuaikan untuk anak usia dini

3. Komponen isi atau materi.

Materi vlog diambil dari keadaan siswa sehari-hari di sekolah, hal-hal yang akan mudah dipahami dan diingat dari kebiasaan yang biasa mereka lakukan. Bentuk-bentuk karakter direkam dari aktivitas dan tindakan yang dilakukan anak usia dini dari pertama datang ke sekolah. Kemudian hasil rekaman itu diperlihatkan lagi kepada mereka. Mereka melihat sendiri diri mereka yang sudah memiliki karakter yang diharapkan atau belum. Materi yang direkam dalam vlog lebih nyata dan memang mereka temukan. Komponen ketiga juga telah melewati proses validasi dari validator pendidikan.

Pembelajaran karakter pada anak usia dini merupakan pembelajaran yang menerapkan perilaku-perilaku baik yang harus dimiliki oleh setiap anak dengan cara melibatkan anak didik dan lingkungannya yang diintergrasikan dalam aktivitas mereka sehari-hari.
Saat ini vlog menjadi kegiatan yang sedang tren di masyarakat. Setiap orang bisa membuat vlog apapun untuk dibagikan di media sosial agar bisa dilihat oleh semua orang. Kesempatan inilah yang digunakan guru untuk dapat memberikan pembelajaran yang lebih mengasikkan dan juga kekinian.

Pembelajaran karakter dilakukan secara terencana dan terus menerus. Agar pembelajaran tersebut berhasil, maka menggunakan contoh yang tidak jauh dari dari siswa atau bisa langsung dilihat.

Pembelajaran karakter selalu diulang oleh guru dalam keseharian anak usia dini di sekolah. Cara yang digunakan guru masih konvensional. Guru masih mengandalkan untuk menggunakan contoh/model dari guru itu sendiri.

Untuk menjawab tantangan perkembangan teknologi yang pesat, diikuti dengan kemampuan yang dimiliki, guru memanfaatkan vlog untuk pembelajaran karakter.

Pada awalnya guru merasa tertantang untuk mengajarkan penanaman nilai-nilai karakter pada anak menggunakan media yang selama ini belum dicoba. Selanjutnya, dengan pengetahuan yang dimiliki, guru mampu memanfaatkan vlog untuk pembelajaran karakter.

vlog yang disajikan terdapat beberapa karakter yang harus dimiliki atau dikuasai oleh anak usia dini. Sehingga guru hanya memperlihatkan vlog tersebut sebagai media untuk mengajarkan pendidikan karakter. Vlog yang digunakan oleh guru merupakan vlog hasil karya peneliti bersama tim dalam memvisualisasikan bentuk karakterkarakter yang harus dimiliki oleh anak usia dini.

Kegiatan yang disimulasikan merupakan kegiatan keseharian anak paud mulai dari mereka datang, belajar di kelas, hingga pulang. Setiap kegiatan tersebut mengandung nilai-nilai karakter yang harus dimiliki oleh seorang anak.

Badan Penelitian dan

Pengembangan, PusatKurikulum

Kementerian Pendidikan Nasional (2011:10) telah merumuskan 
materipendidikan karakter yang terdapat 18

\begin{tabular}{|c|c|}
\hline Nilai & Deskripsi \\
\hline 1. Religius & $\begin{array}{l}\text { Sikap dan perilaku yang } \\
\text { patuh dalam melaksanakan } \\
\text { ajaran agama yang } \\
\text { dianutnya. Toleran terhadap } \\
\text { pelaksanaan ibadah agama } \\
\text { lain }\end{array}$ \\
\hline 2. Jujur & $\begin{array}{l}\text { Perilaku didasarkan pada } \\
\text { upaya menjadikan dirinya } \\
\text { sebagai orang yang selalu } \\
\text { dapat dipercaya dalam } \\
\text { perkataan, tindakan, dan } \\
\text { pekerjaan }\end{array}$ \\
\hline 3. Toleransi & $\begin{array}{l}\text { Sikap dan tindakan yang } \\
\text { menghargai } \\
\text { agama, suku, etnis,pendapat, } \\
\text { sikap, dan tindakan orang } \\
\text { lain yang berbeda dari } \\
\text { dirinya }\end{array}$ \\
\hline 4. Disiplin & $\begin{array}{l}\text { Tindakan yang menunjukkan } \\
\text { perilaku tertib dan patuh } \\
\text { pada berbagai ketentuan dan } \\
\text { peraturan }\end{array}$ \\
\hline $\begin{array}{ll}\text { 5. } & \text { Kerja } \\
\text { keras }\end{array}$ & $\begin{array}{l}\text { Perilaku yang menunjukkan } \\
\text { upaya sungguh-sungguh } \\
\text { dalam mengatasi berbagai } \\
\text { hambatan belajar dan } \\
\text { tugas,serta menyelesaikan } \\
\text { tugas dengan sebaik-baiknya }\end{array}$ \\
\hline 6. Kreatif & $\begin{array}{l}\text { Berpikir dan melakukan } \\
\text { sesuatu untuk menghasilkan } \\
\text { cara atau hasil baru dari } \\
\text { sesuatu yang telah dimiliki }\end{array}$ \\
\hline 7. Mandiri & $\begin{array}{l}\text { Sikap dan perilaku yang } \\
\text { tidak mudah bergantung pada } \\
\text { orang lain dalam } \\
\text { menyelesaikan tugas-tugas }\end{array}$ \\
\hline $\begin{array}{l}\text { 8. Demokrati } \\
\mathrm{s}\end{array}$ & $\begin{array}{l}\text { Cara berpikir, bersikap, dan } \\
\text { bertindak yang menilai sama } \\
\text { hak dan kewajiban dirinya } \\
\text { dan orang lain }\end{array}$ \\
\hline $\begin{array}{l}\text { 9. Rasa ingin } \\
\text { tahu }\end{array}$ & $\begin{array}{l}\text { Sikap dan tindakan yang } \\
\text { selalu berupaya untuk } \\
\text { mengetahui lebih mendalam } \\
\text { dan meluas dari sesuatu yang } \\
\text { dipelajarinya, dilihat dan } \\
\text { didengar }\end{array}$ \\
\hline $\begin{array}{l}\text { 10. Semangat } \\
\text { kebangsaa } \\
\mathrm{n}\end{array}$ & $\begin{array}{lr}\text { Cara berpikir, bertindak dan } \\
\text { berwawasan } & \text { yang } \\
\text { menempatkan } & \text { kepentingan } \\
\text { bangsa dan Negara diatas } \\
\text { kepentingan diri dan } \\
\text { kelompoknya }\end{array}$ \\
\hline
\end{tabular}

\begin{tabular}{|c|c|}
\hline Nilai & Deskripsi \\
\hline $\begin{array}{l}\text { 11. Cinta } \\
\text { Tanah Air }\end{array}$ & $\begin{array}{l}\text { Cara berpikir, bersikap, dan } \\
\text { berbuat yang menunjukkan } \\
\text { kesetiaan, kepedulian dan } \\
\text { penghargaan tang tinggi } \\
\text { terhadap bahasa,lingkungan } \\
\text { fisik, social, budaya, } \\
\text { ekonomi, dan politik bangsa }\end{array}$ \\
\hline $\begin{array}{l}\text { 12. Mengharg } \\
\text { ai Prestasi }\end{array}$ & $\begin{array}{l}\text { Sikap dan tindakan yang } \\
\text { mendorong dirinya untuk } \\
\text { menghasilkan sesuatu yang } \\
\text { berguna bagi masyarakat, } \\
\text { dan mengakui serta } \\
\text { menghormati keberhasilan } \\
\text { orang lain }\end{array}$ \\
\hline $\begin{array}{l}\text { 13. Bersahabat } \\
\text { / } \\
\text { Komunika } \\
\text { tif }\end{array}$ & $\begin{array}{l}\text { Tindakan } \\
\text { memperlihatkan ras senang } \\
\text { berbicara, bergaul, dan } \\
\text { bekerja sama dengan orang } \\
\text { lain }\end{array}$ \\
\hline $\begin{array}{l}\text { 14. Cinta } \\
\text { Damai }\end{array}$ & $\begin{array}{l}\text { Sikap, perkataan, dan } \\
\text { tindakan yang menyebabkan } \\
\text { orang lain merasa senang dan } \\
\text { aman atas kehadiran dirinya }\end{array}$ \\
\hline $\begin{array}{l}\text { 15. Gemar } \\
\text { Membaca }\end{array}$ & $\begin{array}{l}\text { Kebiasaan menyediakan } \\
\text { waktu untuk membaca } \\
\text { berbagai bacaan yang } \\
\text { memberikan kebajikan bagi } \\
\text { dirinya }\end{array}$ \\
\hline $\begin{array}{l}\text { 16. Peduli } \\
\text { Lingkunga } \\
\mathrm{n}\end{array}$ & $\begin{array}{l}\text { Sikap dan tindakan yang } \\
\text { selalu berupaya mencegah } \\
\text { kerusakan pada lingkungan } \\
\text { alam disekitarnya, dan } \\
\text { mengembangkan upaya- } \\
\text { upaya untuk memperbaiki } \\
\text { kerusakan alam yang sudah } \\
\text { terjadi }\end{array}$ \\
\hline $\begin{array}{l}\text { 17. Peduli } \\
\text { Sosial }\end{array}$ & $\begin{array}{l}\text { Sikap dan tindakan yang } \\
\text { selalu ingin memberi bantuan } \\
\text { kepada orang lain dan } \\
\text { masyarakat } \\
\text { membutuhkan }\end{array}$ \\
\hline $\begin{array}{l}\text { 18. Tanggung } \\
\text { jawab }\end{array}$ & $\begin{array}{l}\text { Sikap dan perilaku seseorang } \\
\text { untuk melaksanakan tugas } \\
\text { dan kewajibannya yang } \\
\text { seharusnya dia lakukan, } \\
\text { terhadap diri sendiri, } \\
\text { masyarakat, lingkungan } \\
\text { (alam, social dan budaya), } \\
\text { negara dan Allah Yang } \\
\text { Mahas Esa }\end{array}$ \\
\hline
\end{tabular}

Delapan Belas nilai-nilai karakter tersebut terdapat dalam setiap kegiatan siswa di dalam kelas. Keadaan inilah yang direkam dan dibuat dalam vlog kemudian 
digunakan kembali sebagai media pembelajaran.

\begin{tabular}{|c|c|}
\hline Karakter & Aktivitas Anak \\
\hline 1. Religius & $\begin{array}{l}\text { a. } \text { mengawali dan } \\
\text { mengakhiri kegiatan } \\
\text { dengan membaca doa } \\
\text { b. kegiatan makan }\end{array}$ \\
\hline 2. Jujur & $\begin{array}{l}\text { a. menjawab pertanyaan } \\
\text { dengan benar }\end{array}$ \\
\hline 3. Disiplin & a. datang tepat waktu \\
\hline 4. Santun & b. menyalami guru \\
\hline 5. Bersahabat & a. Menyapa teman \\
\hline 6. Tertib & \begin{tabular}{|ll} 
a. & masuk ke kelas satu per \\
satu secara teratur
\end{tabular} \\
\hline 7. Mandiri & $\begin{array}{l}\text { a. } \begin{array}{l}\text { memasuki kelas tanpa } \\
\text { ditemani atau dibantu } \\
\text { orang tua }\end{array} \\
\end{array}$ \\
\hline $\begin{array}{l}\text { 8. Rasa ingin } \\
\text { tahu }\end{array}$ & $\begin{array}{ll}\text { a. } & \text { mendengarkan } \\
& \text { penjelasan guru dengan } \\
\text { seksama }\end{array}$ \\
\hline 9. Kreatif & \begin{tabular}{|lr} 
a. & $\begin{array}{l}\text { mengkreasikan } \\
\text { atau bentuk }\end{array}$ \\
& $\begin{array}{l}\text { mewarnai } \\
\text { menggambar }\end{array}$ \\
\end{tabular} \\
\hline 10. Menghargai & $\begin{array}{l}\text { 1. } \begin{array}{l}\text { memberikan selamat } \\
\text { dan pujian kepada teman } \\
\text { yang mendapatkan } \\
\text { prestasi }\end{array} \\
\end{array}$ \\
\hline $\begin{array}{l}\text { 11. Gemar } \\
\text { Membaca }\end{array}$ & $\begin{array}{l}\text { a. memperhatikan tulisan } \\
\text { atau buku saat guru } \\
\text { membacakan cerita. }\end{array}$ \\
\hline $\begin{array}{l}\text { 12.Peduli } \\
\text { Lingkungan }\end{array}$ & $\begin{array}{l}\text { a. membereskan peralatan } \\
\text { mainan }\end{array}$ \\
\hline 13.Peduli Sosial & $\begin{array}{l}\text { a. membantu teman yang } \\
\text { mengalami kesulitan }\end{array}$ \\
\hline 14. Cinta Damai & $\begin{array}{l}\text { a. membiarkan kelas tetap } \\
\text { bersih }\end{array}$ \\
\hline 15. Kerja keras & $\begin{array}{ll}\text { a. menyelesaikan tugasnya } \\
\text { tanpa bantuan orang lain }\end{array}$ \\
\hline $\begin{array}{l}\text { 16.Cinta Tanah } \\
\text { Air }\end{array}$ & $\begin{array}{llr}\text { a. } & \begin{array}{l}\text { menggunakan } \\
\text { Indonesia } \\
\text { berkomunikasi }\end{array} & \text { untuk } \\
\end{array}$ \\
\hline
\end{tabular}

Dengan mamanfaatkan video blog ini, guru merasa terbantu dalam mengarahkan siswa-siswa paud untuk selalu menerapkan nilai-nilai karakter tersebut dimana pun berada.

Bukan hanya guru yang merasa terbantu, ternyata siswa juga merasa sangat senang. Terlihat dari antusiasme mereka saat menyaksikan video yang diperankan oleh mereka sendiri. Partisipasi siswa dalam video blog ini dapat memberikan pengalaman yang berbeda pada diri anak. Sehinggan pengalaman ini menjadi pengalaman yang berkesan. Dengan demikian, anak akan selalu mengingat nilai-nilai karakter yang harus selalu diterapkan. Hal itu juga akan mengendalikan sisiwa disaat ia akan berbuat sesuatu yang melanggar nilai-nilai karakteristik.

Pembelajaran yang berkesan tersebut memberikan keuntungan bagi siswa, karena mereka akan menyimpan ingataningatan tersebut untuk jangka waktu yang lama. Tinggal lagi guru untuk selalu melaksanakan hal tersebut.

Wajah-wajah berseri dan senang, membuat guru mereka lebih bersemangat dalam memberikan pelajaran.

Vidoe blog pembelajaran yang dibuat didesain menarik perhatian siswa agar dapat mematuhi aturan-aturan sehubungan dengan nilai-nilai karakter.

Pendekatan yang digunakan guru dalam mengomunikasikan nilai-nilai karakter menjadikan siswa lebih mudah diarahkan untuk melakukan kegiatankegiatan yang menunjukkan nilai-nilai karakter. During direct teaching in the classroom, I give, every word she teaching and learning, a simple, easy level, medium level and high level. So all students according to the level will be observed. (Omar, Noh, Hamzah, \& Majid, 2015)

Jika siswa sudah mudah diarahkan, maka akan mudah bagi mereka untuk meniru kegiatan-kegiatan yang dapat menanamkan nilai-nilai karakter. Kalau mereka sudah mulai meniru, artinya siswa sudah mulai memahami seperti apa karakter yang baik tersebut. sehingga timbul perasaan sukarela untuk melakukan berbagai kegiatan yang berhubungan dengan pembelajaran karakter.

Namun, dalam pembelajaran karakter dengan memanfaatkan vlog ini juga terdapat kesulitan yang dialamai guru saat menggunakan media ini. Salah satu kesulitan yang begitu dirasakan guru adalah pengorganisaasian waktu dan mengintegrasikan ke dalam rencana pembelajaran harian. 
Selain itu, terdapat beberapa anak yang perlu diberikan bimbingan mengenai penerapan nilai-nilai karakter. Seperti halnya anak usia dini, perlu kesabaran dari gurunya untuk mengarahkan anak-anak untuk tetap melaksanakan nilai karakter.

Guru telah memanfaatkan video blog dari segi media, kebahasaan, dan materi untuk pembelajaran karakter pada anak usia dini dengan baik dan sesuai dengan tujuan penelitian yang diharapkan. Dengan memanfaatkan vlog ini mempermudah guru memberikan pengertian dan penjelasan serta menunjukkan wujud nilainilai karakter ada anak usia dini.

Anak memiliki cara dan tipologi belajar yang berbeda-beda. Oleh karena itu, pemilihan model dan media pembelajaran sangat menentukan pembelajaran yang telah berlangsung berhasil atau tidak. Berdasarkan pemikiran Ula (Ula, 2013) cara seseorang menyerap informasi kemudian mengolahnya serta memanifestasikan dalam wujud nyata perilaku hidupnya. Seorang guru yang memahami karakter dan tipe belajar anak didiknya tentu akan memilih media yang bukan hanya mempermudahnya dalam mengajar, tetapi juga membantu anak didiknya memahami pelajaran yang diberikan.

Selanjutnya Mulyasa (Mulyasa, 2014) menerangkan bahwa terdapat Living values education dalam mengembangkan karakter anak dengan asumsi bahwa: 1) nila-nilai universal mengajarkan penghargaan dan kehormatan tiap-tiap manusia, 2) setiap murid benar-benar memperhatikan nilai-nilai dan mampu menciptakan dan belajar dengan positif bila diberikan kesempatan, dan 3) muridmurid berjuang dalam suasana berdasarkan nilai dalam lingkungan yang positif, aman dengan sikap saling menghargai dan kasih saying, murid dianggap mampu belajar menetukan pilihan-pilihan yang sadar lingkungan.

Adapun nilai-nilai yang dikembangkan untuk anak usia dini adalah nilai-nilai kedamaian, penghargaan, cinta, tanggung jawab, kebahagiaan, kerja sama, kejujuran, kerendahan hati, toleransi, kesederhanaan dan persatuan.

Inti dari metode living values education adalah anak-anak harus mengalami nilai-nilai dalam berbagai tingkatan agar nilai-nilai tersebut menjadi bagian dalam diri mereka. Jadi, mereka untuk mendengarkan, merasakan, mengalami, dan menggunakan keterampilan social untuk menggunakan nilai-nilai tersebut dalam kehidupan seharihari.

Keberhasilan pengembangan karakter dalam pendidikan anak usia dini dapat diketahui dari perilaku anak seharihari yang tampak pada aktivitas berikut:

1. Kesadaran

2. Kejujuran

3. Keikhlasan

4. Kesederhanaan

5. Kemandirian

6. Kepedulian

7. Kebebasan dalam bertindak

8. Kecermatan/ketelitian

9. Komitmen

\section{UCAPAN TERIMA KASIH}

Terima kasih kepada Direktorat Riset dan Pengabdian Masyarakat.Direktorat Jenderal Penguatan Riset dan Pengembangan Kementerian Riset, Teknologi dan Pendidikan Tinggi dalam pembiayaan skema Penelitian Dosen Pemula tahun anggaran 2018.

\section{SIMPULAN}

Guru memanfaatkan vlog pada pembelajaran karakter sebagai media pembelajaran untuk membantu menjelaskan dan menunjukkan nilai-nilai karakter yang harus dimiliki dan diterapkan oleh anak usia dini.

Pemanfaat Video blog untuk pembelajaran karakter pada anak usia dini dapat memberikan pengalaman baru bagi peserta didik sehingga pembelajaran akan lebih berkesan. Dengan begitu, akan mudah bagi anak usia dini untuk selalu menerapkan nilai-nilai karakter dalam kehidupan mereka sehari-hari, khususnya di sekolah 


\section{DAFTAR PUSTAKA}

Hudiyono. (2012). Membangun Karakter Siswa Melalui Profesionalisme Guru dan Gerakan Pramuka. Essensi Erlangga Grup. Surabaya: Essensi Erlangga Grup.

Komputer, W. (2008). Langkah Mudah Mengembangkan dan Memanfaatkan Weblog. Yogyakarta:Andi Offset.

Mulyani, N. (2016). Dasar-dasar Pendidikan Anak Usia Dini. Yogyakarta: Kalimedia.

Mulyasa. (2011). Manajemen Pendidikan Karakter. Jakarta: Bumi Aksara.

Mulyasa. (2014). Manajemen PAUD. Bandung: PT. Remaja Rosdakarya.

Omar, N., Noh, M. A. C., Hamzah, M. I., \& Majid, L. A. (2015). Multicultural Education Practice in Malaysia. Procedia - Social and Behavioral Sciences, 174, 1941-1948. https://doi.org/10.1016/j.sbspro.2015. 01.859

Prasanti, D., \& Fitriani, D. R. (2018). Pembentukan Karakter Anak Usia Dini: Keluarga, Sekolah, Dan Komunitas? Jurnal Obsesi : Jurnal Pendidikan Anak Usia Dini, 1(13 19).

Sanjaya, W. (2006). Strategi Pembelajaran Berorientasi Standar Proses Pendidikan. Jakarta: Prenada Media Group.

Suyra, Y. F. (2017). Penggunaan Model Pembelajaran Pendidikan Karakter Abad 21. Jurnal Obsesi : Jurnal Pendidikan Anak Usia Dini, 1(1), 5261.

Ula, S. (2013). Revolusi Belajar (Optimalisasi Kecerdasan melalui Pembelajaran Berbasis Kecerdasan Majemuk). Yogyakarta: Ar-ruzz Media. 